\title{
Sound and Motion in Goethe's "Magic Flute"
}

\author{
JAMES P. RASMUSSEN \\ Indiana University
}

As the theater director in Weimar from 1791 to 1816 , Goethe had a particular interest in Mozartean opera. In his first season he produced Die Entführung aus dem Serail, in 1792 Don Giovanni, in 1793 Le nozze di Figaro, and on January 16, 1794, after personally directing the rehearsals (an unusual practice at that stage of his directorship), he put on his first performance of Die Zauberflöte. For the next twenty-two years - until Goethe resigned as directorMozart was the most frequently performed composer and Die Zauberflöte the most frequent stage play in Weimar. ${ }^{1}$

These performances were enormously successful. The success of Die Zauberföte, along with Goethe's particular interests in both libretto and music, led him to attempt to write a sequel, which he began in 1795 and entitled Der Zauberflöte zweiter Teil. Such a project would be at once a tribute to Mozart, an appropriation of a suggestive symbolic world amenable to his own artistic explorations, and a way of capitalizing on a box office hit. ${ }^{2}$ Though he never finished the project, partly because of difficulties in finding a composer to work with, he did publish it - with eight scenes and outlines of a few more interspersed in between-in Wilmans Taschenbuch auf das Jahr 1802 and again in his collected works of 1807-08.

Some aspects of this fragmentary text will seem very familiar to readers of Goethe's better-known works. The fragment is an important step in the development of major Goethean themes such as metamorphosis and Steigerung, and Dieter Borchmeyer may well be right that one cause for Goethe's loss of interest in the fragment was "daß ihre poetische Substanz inzwischen durch andere Dichtungen verbraucht war," in particular, through Wilhelm Meister and Faust. ${ }^{3}$ But there are other aspects of the text that may not seem so familiar. For Goethe - who described himself as an Augenmensch and a Ton- und Gehörloser ${ }^{4}$ and whose preoccupation with vision has always been a staple of Goethe scholarship_chooses not to retain the universal opposition between light and dark so central to the original libretto, as one might expect, but rather to employ the metaphor of sound, particularly the sound of the human voice, as the vehicle for his thematic explorations. Sound provides access to a third

Monatshefte, Vol. 101, No.1, 2009

(C) 2009 by The Board of Regents of the University of Wisconsin System 
realm of experience, beyond the domains of the Queen of the Night and of Sarastro, high priest of the gods of light, and thereby renders less universal the conflict between dark and light. ${ }^{5}$ Further, Goethe makes distinctions between tones to suggest different relationships and functions and to match stages of individual and cultural growth and Bildung, thus bringing an inchoate hierarchy of sounds to bear on broad cultural concerns. ${ }^{6}$ Precisely how he invests sound with such significance is the primary concern of this essay.

Goethe's treatment of sound links it intimately to movement, and one of his most striking conceptual changes to the Schikaneder libretto is the introduction of a year-long pilgrimage undertaken by one temple priest every year, with the purpose of seeking out "die erhabene Sprache der Natur, die Töne der bedürftigen Menschheit" (234). A second major change makes Tamino and Pamino the parents of an infant son, and the climax (and dramatic ending) of the action is the child's awakening into articulate speech and his flight as a "Genius" or spirit. Whereas the priests wander about the earth seeking to hear sounds, the boy's life - which seems greatly endangered by the machinations of the Queen-culminates in his ability to produce (articulate) sounds, an ability co-existent with his ability to fly.

Goethe's depiction of the boy's awakening reverberates with Friedrich Kittler's exploration of the new role, around 1800, of the mother's voice in instilling a soul in children and awakening them to language and culture. ${ }^{7}$ However, not only the mother's voice but also the wiles of the Queen (that is, the efforts of both sides of the opposition between light and dark) are necessary to awaken the child, who becomes symbolic of a sovereign humanity not bound by divine or demonic powers but rather awakened by their opposition, and thereby enabled to move beyond them.

\section{Sound in the Fragment}

The main contours of the plot are these. ${ }^{8}$ Tamino and Pamina have just had a son, but on the day of his birth he is abducted by the Moor Monostatos (now in the service of the Queen of the Night) and placed in a golden casket. As the Moor tries to carry him off the casket becomes too heavy, due to Sarastro's magic, and he must abandon it. Before doing so, he places the Queen's seal on the casket so it cannot be opened, and he also pronounces two curses in her name: first, in the moment that the parents see their child it will die; second, in the moment that the two parents look at each other, they will fall into fits of madness. (One notes that the curse extends only over the sense of sight; the Queen, it turns out, has no power over the sense of hearing.) Sarastro's priests recover the child, but cannot open the casket. The child and casket are entrusted to the ladies of Tamino's palace-Tamino has taken over secular leadership of the community surrounding the temple brotherhood-and they are told that they must keep the casket in constant movement. 
In the meantime, Sarastro has been chosen by the gods to leave on a year-long pilgrimage. Shortly after leaving, he encounters Papageno and $\mathrm{Pa}-$ pagena in their country home, who use the Glockenspiel and the Zauberföte, familiar from the opera, to lure wild animals that they then catch and eat (thus the flute, music-instrumental representative of virtue in the opera, here becomes "instrumentalized" in another, parodic way). They are sad because they still have no children, but with Sarastro's help three giant eggs appear, out of which hatch three bird-children. Sarastro then tells them of the troubles at court, and Papageno takes the magic flute (which Tamino had given him as a wedding present) to try to help Tamino and Pamina feel better, though the flute can only help temporarily.

Once Sarastro has left, the Queen's powers seem to increase: she regains control over the child by making the casket sink into the earth, and she guards it with soldiers, lions, fire, and water. Tamino and Pamina discover where their child is and struggle to reach him-passing through fire and water, just as in Mozart's opera-and as they do so he hears their voices, opens the casket, speaks, and, described as a "Genius" or spirit, flies away. There the fragment ends. ${ }^{9}$

As mentioned, one of Goethe's most striking innovations is the introduction of year-long priestly pilgrimages. Sarastro explains:

In diesen stillen Mauern lernt der Mensch sich selbst und sein Innerstes erforschen. Er bereitet sich vor, die Stimme der Götter zu vernehmen; aber die erhabene Sprache der Natur, die Töne der bedürftigen Menschheit lernt nur der Wandrer kennen, der auf den weiten Gefilden der Erde umherschweift. In diesem Sinne verbindet uns das Gesetz, jährlich einen von uns als Pilger hinaus in die rauhe Welt zu schicken. Das Los entscheidet, und der Fromme gehorcht. (234-35)

As one would expect, the goal of the temple, with its still walls, is to provide a place in which to perceive "die Stimme der Götter." But surprisingly, these are not the only voices the priests are commanded to seek out. There are other voices that cannot be heard inside the temple: "die erhabene Sprache der Natur, die Töne der bedürftigen Menschheit." Vital experiences of nature and humanity can only be gained outside the temple; and that realm outside, as opposed to the quiet of the temple society, is a world of sound.

To gain the necessary experience, the priests enter a new, autonomous realm, leaving behind the binary oppositions that define their own world. For the pilgrims are not leaving the temple simply to enter into the Queen's domain: she, too, belongs only to the world of light and dark. The first scene of the fragment, in which the Queen makes an appearance and we are indirectly debriefed on the new situation in which the characters find themselves, already introduces the thematics of sound as a realm beyond the Queen's control. The Queen is not visible at first; it is the Moor Monostatos who summons her, rather unwilling: 


\author{
O Göttin! [ . . . ] \\ $\mathrm{O}$ höre deinen Freund! höre deinen künftigen Gatten! \\ Was hindert dich, allgegenwärtige Macht, \\ Was hält dich ab, o Königin der Nacht, \\ In diesem Augenblick uns hier zu überschatten! (223)
}

At these words there is a thunderclap, sudden darkness, and clouds; then the Queen appears. But unlike her first words in the opera ("O zittre nicht, mein lieber Sohn!" ${ }^{10}$ ), her words here do not reveal her awareness of her own power nor her awareness of who stands before her. Instead, her first words are a gloomy questioning:
Wer ruft mich an?
Wer wagt's, mit mir zu sprechen?
Wer, diese Stille kühn zu unterbrechen?
Ich höre nichts—-so bin ich denn allein!
Die Welt verstummt um mich—so soll es sein. (223-24)

The stage directions clarifies that despite the clouds, which continue to spread over the stage as the Queen speaks, Monostatos and his troupe are still visible. But she does not see them, and continues:
Woget, ihr Wolken, hin,
Decket die Erde,
$\mathrm{Da}$ es noch düsterer,
Finsterer werde!
Schrecken und Schauer,
Klagen und Trauer
Leise verhalle, bang
Ende den Nachtgesang
Schweigen und Tod. (224)

While the Queen is certainly still the Queen of the Night and darkness is still her provenance, the main thrust of her words aim more at silence than at darkness. Her realm, too, like the temple, is a quiet one. It is the silence of her self-withdrawal that Monostatos has broken, reawakening her to the broader world, and it is ultimately to regain that silence that she commands the clouds. Though she has heard Monostatos' voice, she does not know whose voice it was, despite his having stressed his identity as friend and future spouse. It is not the identity of the speaker, nor the precise words, but rather the sheer sound of the voice that reaches and awakens her. Thus, she must ask who has spoken; receiving no answer, she states: "Ich höre nichts—so bin ich denn allein!" (224). The sound of a voice is what announces presence; silence means absence.

Thus both Sarastro and the Queen rule over realms of silence, which are therefore also realms of absence, of lack: the silent walls of the temple corre- 
spond to the silence of the Queen's inward brooding. Whereas the Queen seeks to draw others (particularly the child) into her own closed realm, in which she herself also prefers to remain, the temple brotherhood, as we have seen, is commanded to leave its own realm for yearlong pilgrimages, seeking out the sounds of the world beyond the frame of their binary opposition as a necessary supplement to the temple community. Thus sound is invested with utopian significance, as a dimension of experience without which the (presumably) otherwise perfect temple community is insufficient. And what the pilgrims seek, the boy - already the bearer of utopian expectations simply through his parentage-will soon create himself.

Even before waking, the child is marked out as different, through the command to the child's care-takers to keep him in constant movement. The reason for this command is not clear (though it reminds one of Faust's deal with Mephistopheles), as one of the servants acknowledges: "So wandelt fort und stehet niemals stille, / Das ist der weisen Männer Wille, / Vertraut auf sie, gehorchet blind; / So lang ihr wandelt lebt das Kind" (105). Tamino had prayed to the gods to sustain the infant while trapped in the casket, and after doing so he seems to understand that the child lives through movement: he exclaims (to the gods and to the care-takers): "Ihr Götter! schützet [das Kind] auf wunderbare Weise. Erquickt's mit eurem Trank! Nährt es mit eurer Speise! Und ihr beweis't mir eure Treue. Bewegt euch immer fort und fort!" (229).

Goethe thus emphasizes the mobility of child and pilgrim on the one hand, and on the other, the static immobility of the Queen and of the temple society as such. To explain this stark contrast, Dieter Borchmeyer refers to Goethe's "privaten Schöpfungsmythos" outlined in Book 8 of Dichtung und Wahrheit, which emphasizes a continuous exchange between principles of concentration and of expansion. The Queen, for Borchmeyer, embodies the inward-looking, closed principle of concentration, and the priestly order with its yearly pilgrimages embodies the principle of expansion. ${ }^{11}$ Such an argument is persuasive in its insistence that priests and Queen are ultimately complementary despite their opposition. But if we remain committed to a simple binary opposition between the temple order and the Queen's kingdom, as Borchmeyer does, we lose both an important distinction between the pilgrimages and the temple order as such, and also an appreciation of the unique position of the child.

The priestly ideology does not enjoin movement as an absolute principle, as the tight controls imposed by the rituals associated with the yearly pilgrimages make clear. Only a single priest is chosen by the gods to be a pilgrim, and he is only to wander for one year. Upon his return he must prove whether he has maintained his purity:

Der Sprecher. Vor der nördlichen Pforte unserer heiligen Wohnung stehet unser Bruder, der die Pilgrimschaft unseres Jahres zurückgelegt hat und wünscht 
wieder eingelassen zu werden. Er übersendet hier das gewisse Zeichen, an dem du erkennen kannst daß er noch wert ist, in unsere Mitte wieder aufgenommen zu werden.

Er überreicht Sarastro einen runden Kristall an einem Bande.

Sarastro. Dieser geheimnisvolle Stein ist noch hell und klar. Er würde trüb erscheinen wenn unser Bruder gefehlt hätte. Führe den Wiederkehrenden heran! (234)

We know nothing about the world outside except that there one wanders, and that there the language of sublime nature and the tones of needy humanity can be heard. Although humanity is "needy," the pilgrim's goal, it appears, is not to administer to those needs (at least on any large scale) but to become aware of them and then to return, for purposes of personal development. As Sarastro says to the returning priest: "Der Krystall zeigt mir an, daß du reines Herzens zurücke kehrst, das keine Schuld auf dir ruht. Nun aber teile deinen Brüdern mit, was du gelernt, was du erfahren hast, und vermehre die Weisheit, indem du sie bestätigst" (235). Presumably, his goal as a pilgrim has been to experience some degree of identification with the foreign worlds of nature and humanity - whether through awe at natural sublimities, pity for human needs, or some other affective response - and then, after this identification with the outside world, to return home and identify better with the "inside" world, having developed an increased understanding of himself and his place.

As Bildung the pilgrimage requires a return-yet there is a risk that the pilgrim will be unable to do so. The pilgrim is on a holy mission, having received a holy call, but his path is fraught with moral dangers. At the same time that his pilgrimage enables the spiritual and holy experiences he seeks, the region in which he moves also enables other experiences that could taint his soul and make him unfit for the community of light. Whatever forms his identification with the outside world may take, his return to the temple and the ritual test for purity will reveal whether those forms are compatible with the network of identifications and associations to which he is returning. If they are not, the returning pilgrim will be turned away and, having no home, will presumably be doomed to wander continuously.

From the priests' perspective, then, perpetual movement is a punishment, or at any rate a symptom and consequence of impurity and of isolation. Yet the priority they place on returning is in stark contrast to the events associated with the child. The servants, we recall, do not understand why they must keep the child (in the casket) in constant movement, and their bafflement may stem precisely from the priestly ideology that emphasizes the return home. ${ }^{12}$ But symbolically, and in conjunction with the child's later ability to fly, the priests' declaration-So lang [er] wandelt, lebt das Kind—emphasizes that the child does not belong to the stationary world of the temple community, nor to that of the Queen, but to a different world, a world of perpetual movement — which 
is the world traversed by the pilgrim, the world of sound. In the child's ability to speak and to fly, once awakened, he instantiates the mobility of sound and represents the world beyond the binary opposition of priest and Queen. ${ }^{13}$ If he represents an ideal humanity, as his parentage suggests, then the sounds he produces upon flying away to the world outside the frame will find their place among the sounds the pilgrims are seeking to hear. One could speculate further that this boy-spirit might bring a unifying harmony to sublime nature and needy humanity and thus fulfill the latter's need.

As the text stands, of course, the boy-spirit's flight is not prompted by such a goal. For him, as for the pilgrims, there is no point of arrival beyond the polarized world of the temple and the Queen; there is simply sound, coming into being as an expression of continual movement that has no telos other than its own motion. But whereas the pilgrim does have the express goal of returning home eventually, the boy does not—he has no goal at all. His flight is curiously uninterested, almost unintentional. Escape is not a particularly strong motivation, since he already knows the guards have no power over him; and in leaving them he also leaves his loving parents, without a word of farewell. The scene is fragmentary of course, and some of the paralipomena-elliptical notes recording some of Goethe's ideas for future work on the project-could be interpreted to suggest that the boy may need help again from his parents ("Genius wird gefangen" [ . . . "Tamino siegt" (1064)), with the implication that he is not yet fully self-sufficient and that the forces of light and dark still have more battles ahead of them until he is. But as the published text stands, he appears already to be so.

The utopian import of the boy's self-sufficiency, coming about as it does through the particular events of his awakening, are further strengthened by his parentage: in the genetic image of the family, the boy-spirit combines within himself not only the opposed worlds of light and dark (the Queen is his grandmother and Sarastro, in effect, his adoptive grandfather) but also, on a different plane of opposition, both the world of the magic flute in which light and dark are locked in conflict (Pamina is daughter of the Queen but also of a man who is intimately connected to Sarastro's brotherhood ${ }^{14}$ ) and the world of nature and humanity, the world outside the frame-for that is the world from which Tamino once came, driven by great need as he fled a giant snake..$^{15}$ Now his son, no longer feeling any need whatsoever, is apparently going back out into the human world and is impervious to the dangers that threatened Tamino, as his final words emphasize: "Und drohten mir Drachen; / Sie haben doch alle / Dem Knaben nichts an" (249). Tamino, it seems, is or was a member of "needy" humanity; his entrance into the world of the magic flute and his union with Pamina fulfills his own needs but may be only the first step in a larger historical and generational trajectory that reaches its fulfillment in the boyspirit's return to the world of men, symbol of a god-like humanity that results from the successful union of worlds. 


\section{Awakening the Child}

The fragment as we have it is less concerned with the realization and depiction of a utopian society than with symbolism suggestive of its imminent establishment. The crux of this symbolism is the boy's awakening, and I turn now to consider that event in more detail.

I will begin by noting that the magic flute has nothing to do with it. This may be somewhat surprising, given its role in the original opera and the importance Goethe places on sound. After having highlighted limitations to Sarastro's and the Queen's powers by privileging sound, Goethe then goes out of his way to highlight the flute's limitations as well: it does not produce quite the right sounds, it seems. The flute's most crucial function in the original opera had been to allow Tamino and Pamina to pass through trials of fire and water as the final step before successfully entering the temple. ${ }^{16}$ Goethe's sequel also includes barriers of fire and water, and his stage directions indicate his express desire to bring the original to mind: "Dekoration des Wassers und Feuers, wie in der Zauberflöte. Links das Feuer, eine kleine freie Erhöhung, wenn man da durchgegangen ist; alsdann das Wasser, oben drüber ein gangbarer Felsen, aber ohne Tempel" (247). But the overt parallels ultimately only serve to highlight more clearly the differences: here the fire and water are no longer trials of initiation intended to be overcome, with a temple as the goal, but rather barriers erected by the Queen to keep them away; and now Tamino and Pamina have no recourse to the magic flute.

Tamino no longer even owns the flute: he has given it to Papageno as a wedding gift. By the time Sarastro, having embarked on his pilgrimage, stops by Papageno's cottage and speaks of the sorrows at court, the child and casket have already fallen into the Queen's hands, and Tamino and Pamina suffer from the despair prophesied by Monostatos. Sarastro encourages Papageno to visit his friends and use the flute's "heilende Kraft" to try to ease their pain (238). But as soon as Papageno brings the flute to court, its limitations become apparent. As long as he plays, the couple embraces, joyful at being in one another's presence, but whenever he stops for breath, Tamino and Pamina withdraw from their embrace and exclaim: "Ach was hat man uns genommen! / O wie leer ist dieses Haus!" (244). As soon as Papageno resumes, they embrace and exclaim: "Nein, man hat uns nichts genommen, / Groß und reich ist unser Haus" (245) This rapid leap between opposing sentiments occurs several times, as Papageno must stop to draw breath often: it is no small irony, and presumably much of the intended humor of the scene, that he still has enough breath to tell us "Ach mir bleibt der Atem aus!"17

Thus, the flute certainly produces an effect on the grieving parents, similar to its effects on Monostatos and on the wild animals in the opera, but here the limitation of these effects is highlighted. The flute's sounds are a memory filter: when it is played, Tamino and Pamina do not remember they have had 
a child; when it stops, they again remember their son and his abduction. Thus the flute mentally transports the couple to an earlier time, before the birth of their child: in other words, to the point in time at which the original opera ended, after they had successfully passed their trials and were just entering what Borchmeyer calls the "Mysterium der Ehe." ${ }^{18}$ But Goethe's fragment is oriented around the new situation that the child represents, and the flute clearly has artificial rather than real power in the face of that new situation: it only deceives them into forgetting their current experience. While it may serve to lighten the burden of grief for the parents, the relief it provides is only temporary.

Some questions do remain as to the flute's powers: before Papageno plays the flute, as we have seen, the two parents have been suffering from despair, but at a later point they see each other (and then pass through the fire and water together) with no ill effects. Possibly the flute has had a permanent, though limited, effect in overcoming the first part of Monostatos' curse (the part that omits any mention of the child but focuses on the couple). This too would suggest that the flute's proper function is to unite the loving pair, as in Mozart's opera, and confirms the conclusion that the flute is essential for the "Mysterium der Ehe" but not for their new experiences, which Borchmeyer calls the "Mysterium der Mutterschaft und Familie"19 — once again the flute overcomes the obstacles keeping the lovers apart, and it is ultimately left behind, at the passage through fire and water, for a new, more appropriate instrument of power.

This new "instrument," it turns out, is Pamina's motherly love, expressed through her voice. Tamino and Pamina have discovered where their son is being kept (still in the casket) and as they pass through the barriers of fire and water erected by the Queen to keep them away, they cry out:

O mein Gatte, mein Geliebter,

Meine Gattin, meine Teure,

Sieh, das Wasser, sieh das Feuer

Macht der Mutterliebe Platz. (247-48)

Shortly afterward, the child in the casket, still unseen, begins to speak:

Die Stimme des Vaters

Des Mütterchens Ton,

Es hört sie der Knabe

Und wachet auch schon. (248)

Thus, the child awakes because of the sound of his parents' voices, which in turn can only reach him because of his mother's love. And now that the child is awake and has begun to speak, the Queen's seal and curse are shown to have no more effect: he opens the casket effortlessly, and his parents see him without any harm befalling him. Goethe specified with great care that the audience 
should see him as a "Genius," a spirit of light hovering over the opened casket. ${ }^{20}$ The boy speaks further, asserting his complete invulnerability, and at the end he flies away:

Hier bin ich, ihr Lieben!

Und bin ich nicht schön?

Wer wird sich betrüben,

Sein Söhnchen zu sehn?

In Nächten geboren,

Im herrlichen Haus,

Und wieder verloren

In Nächten und Graus.

Es drohen die Speere,

Die grimmigen Rachen-

Und drohten mir Heere

Und drohten mir Drachen,

Sie haben doch alle

Dem Knaben nichts an. (249)

In Aufschreibesysteme 1800/1900, Friedrich Kittler has explored the new role of the mother's voice in awakening children to language and culture: around 1800, "[d]ie Mutter und nur sie erzieht Menschen, die einzig und gänzlich Menschen sind." ${ }^{21}$ New pedagogical techniques developed by Pestalozzi and others emphasized the mother's role in bringing her children to speech, reading, and writing - a process that begins with teaching them to listen to her voice. As Pestalozzi writes in a treatise entitled "Über den Sinn des Gehörs, in Hinsicht auf Menschenbildung durch Ton und Sprache":

Lavater sagte: wer hören kann, kann alles, und er hatte recht. Insofern das Hören uns durch das Reden zum eigentlichen menschlichen Gebrauch der übrigen Sinne und überall zur allgemeinen Entwicklung der Anlagen und Krafte unserer Nature hinführt, insofern ist das Hörenkönnen das allgemeine Fundament unserer Veredlung. Und Mutter, du hast eine Kraft, dieses Fundament zur Veredlung deines Kindes zu legen, die niemand hat. Es ist dein Pflicht, dieses Fundament zu legen; du sollst dein Kind hören lehren. ${ }^{22}$

The mother was believed to be the best instructor in large part because of the strong affectionate bond that was now theorized to exist between mothers and their children, and the very concept of "mother" took on a new significance, becoming a "neue Bestimmung des Weibes" in which women were mothers above all else. ${ }^{23}$ In the same treatise, Pestalozzi claims: "[Die Natur] hat die Mutter unwillkührlich und instinktartig zu der hohen Neigung erhoben, in ihrem Geiste und mit ihrer Kraft allgemein zur Entwicklung der Anlagen und Fertigkeiten ihres Kindes mitzuwürken." ${ }^{24}$ Once a woman becomes a mother, she is all mother.

With respect to the mother's role, Goethe's sequel belongs to what Kittler calls the network of 1800, while Mozart's opera remains decidedly in an 
earlier age. Goethe's Pamina brings her child to speech through the expression of her love, which is articulated jointly with Tamino. The child shows no awareness of having understood what they said-he does not acknowledge the anguish and the difficulties of his parents - but seems only to have recognized the sound of their voices and thus to have become aware that they are nearby. The child does not hear words but hears the concrete sound of their voices sending a message of their presence and, presumably, of their love (though he only acknowledges this love obliquely, when he asks: "Wer wird sich betrüben / Sein Söhnchen zu sehen?"). After hearing them he himself awakes, bursts open the casket, and speaks.

His articulate voice now contrasts with the inarticulate sounds he had produced previously from within the casket. When a worried Tamino had earlier asked if the boy were still alive, the care-takers had told him:

Wenn mit betrübten Sinnen

Wir wallen und wir lauschen;

So hören wir dadrinnen

Gar wunderlich es rauschen.

Wir fühlen was sich regen,

Wir sehn den Sarg sich bewegen,

Wir horchen und wir schweigen

Auf diese guten Zeichen.

Und Nachts, wenn jeder Ton verhallt;

So hören wir ein Kind das lallt. (229)

Movement and sound are again paired here, and both are also tied to the beginning of self-consciousness: the unconscious self is moved about until it awakens and can move purposefully of its own volition. The boy's babbling and first movements accompany the external motion of the casket, and his beginning to speak announces his awakening - via his parents' voices and above all his mother's love-into self-awareness and self-conscious movement.

The mother's loving voice in Goethe's sequel, as the marker of humanity that awakens the child, is a precise counterpoint to the inhumanity of another mother's very unloving voice in the original opera: that of the Queen's second aria ("Der Hölle Rache kocht in meinem Herzen"25). Much of the thrust of Goethe's sequel can be seen as a reaction against that aria: it may in part be his response to the Queen that leads this self-described Augenmensch to make of sound so important a theme. His target is partly her words and the kind of mother they reveal (she threatens to disown her daughter if she does not help to murder Sarastro), but also what Carolyn Abbate calls the "sonorous texture" of the music itself. ${ }^{26}$ Of the Queen's aria Abbate writes:

I would read the aria [ ... ] as oscillating between drama-the angry tirade by the character-and voice-object that comes to the fore precisely in the melismatic vocalises, for the melismas, by splitting words ("nimmermehr," "Bande") and separating syllable from syllable, destroy language. So the Queen, by killing 
language, also kills plot, and herself as a character. She suddenly becomes not a character-presence but an irrational nonbeing, terrifying because the locus of voice is now not a character, not human, and somehow not present. ${ }^{27}$

The ostensible human speaker is not present; but the voice itself certainly is in all its immediate, inarticulate power. When the florid lines of the melismas begin all attention is riveted on that voice; as Abbate writes, character, plot, stage, even the orchestra all drop out of the perceptual field and we are "assailed" by the music's "sheer sound" $(\mathrm{x}) .^{28}$

Thus one way to view Goethe's sequel is as an attempt to contain the danger of a "voice without a physically present human character," a voice ostensibly that of a mother but existing solely in the physical force of its own sound without human signification. ${ }^{29}$ In this reading, it is her de-humanized voice that haunts Goethe, who, unable to resist the magic power of her voice, seeks to incorporate the power of voices into his text, guarding against her overpowering non-articulation by ensuring the human signification of the voices he allows into his narrative. For Goethe, the human voice ought to be an infallible sign of human presence. His thinking here follows the tradition in which Rousseau also stood, who had written in his Essai sur l'origine des langues that "[1]es sons annoncent le movement; la voix annonce un être sensible." ${ }^{30}$ Rousseau had famously praised song as the highest musical genre precisely because of its inclusion of the human voice, and for both Rousseau and Goethe, the implied human presence is their ultimate concern: music is at its best when it is firmly and explicitly tied to the human source of its production, and no instrument is better suited to that purpose than the human voice: "il n'y a que des corps animés qui chantent." 31

The coloratura lines of the Queen's aria could seem-and certainly do in Abbate's reading - to present a challenge and an affront to this ideological position. It may be, then, that Goethe is seeking to transmute the overwhelming, irrational voice of Pamina's mother into the voice of a new kind of mother, a voice that is still inarticulate but that gives evidence of the presence and the humanity of its speaker, in that it expresses the mother's love. The result (as laid out on paper, though Goethe of course found no composer to flesh it out) is a sounding voice that empowers its listeners - leads to articulation, to speech, to the culture of the pen-rather than entrapping them in its own inarticulate realm.

Thus Goethe's attempt at a sequel not only provides a striking instantiation of many aspects of Kittler's account but also charts the process of change in such roles: we see in Pamina the new mother who lovingly leads her child to language, and we also see an older mother-both literally and conceptually - in the figure of the Queen, who is, of course, the boy's grandmother: the changing functions of motherhood are registered as generational differences. The Queen's relationship to Pamina is a troubled one in the opera, and 
in Goethe's text it is the Queen - the interfering grandparent who rejects the new pedagogical techniques - who makes difficult Pamina's new function as a mother, as if to suggest what Kittler himself ignores, namely the difficulty of the cultural transition to the "neue Bestimmung des Weibes." 32

Kittler's work, then, does not fully account for the symbolic import of Pamina and the Queen; nor does it succeed in "domesticating" the strangeness of the boy's awakening and subsequent behavior. The child does not only speak immediately upon awakening, but also flies. And the first step of that awakening — or at any rate an essential preliminary step-is not hearing his mother's loving voice, but becoming trapped in the casket. For all her ostensible desire to harm the child, the Queen nevertheless plays a crucial role in the boy's development: it is striking that after regaining control of the casket she does not kill him but simply guards him, suggesting that her role, whatever her overt intentions, may actually play a part in furthering the child's life. Thus the meddling grandmother with the outdated mothering techniques may be as instrumental to the boy's development as the new, Kittlerian mother. The casket is powerfully suggestive of a cocoon, and Borchmeyer has compared the boy's awakening to that of a chrysalis: ${ }^{33}$ being trapped in the casket would then be a necessary step in becoming a creature that can fly. Yet this is a strange kind of metamorphosis in which the boy's parents and the Queen are activeand actively struggling - agents in the process of his awakening, rather than impartial conditions of nature (e.g. sunlight) as the analogy to the chrysalis might imply. The boy's awakening is an event that requires active efforts by both the parents on the side of light and the Queen on the side of the dark. But then, once awake, he no longer needs any of them. When he leaves behind the worlds of the Queen and of the temple brotherhood to which his parents belong, the boy literally rises above and beyond the conflicts of light and darkness, of good and evil, that he is born out of and that awakened him.

Kittler's findings, then, resonate with one crucial aspect of Goethe's attempt to represent the genesis and awakening of a figure invested with utopian significance as a representation of self-sovereign humanity, but cannot provide a complete account of its strangeness. While the focus on the mother's voice does make the mechanism of this genesis look like organic development along the lines of a Kittlerian analysis of cultural forces around 1800, the Queen's involvement gives a different tenor to this organic model by including a strongly agonistic dimension. The child is born out of contraries and conflicts, and it is precisely the conflict that sets the stage for his awakening. Further, the boy's awakening seems to occasion, or be coincidental with, a change of being - now no longer simply the offspring of his parents but a new kind of creature altogether, a "Genius" who can fly — and this decisive mutation calls into some question a smoothly gestational, organic model for the birth of a utopian humanity, and suggests rather a model of ruptures or leaps. If this is an evolutionary model of the rise of a utopian humanity, it 
is an evolutionary process marked not by continuities but by discontinuities and disjunctures.

The result of this rupture that is the boy's awakening is his finding his voice and his setting himself into movement. It is a leap from silence and immobility to sound and motion. Though we know little about what the boy-child will do or where he will go, it is clear that movement is crucial to Goethe's vision of him: like Faust, the child does not rest. But whereas Faust's restlessness is motivated by his own dissatisfactions, the child's movement is unmotivated. The spirit-child who flies does not do so out of restlessness, but simply because he can, because it is his nature. The child engages in - and perhaps represents - movement for its own sake. This also differentiates him from Faust's son Euphorion. Euphorion, too, leaves his parents to enter the world and attempts to fly, but his attempt fails. Upon reaching the top of a mountain he jumps off and cries: "Dorthin! Ich muß! ich muß! / Gönnt mir den Flug!" (9899-9900). ${ }^{34}$ He then throws himself into the air, where "die Gewande tragen ihn einen Augenblick, sein Haupt strahlt, ein Lichtschweif zieht nach" (before line 9901). ${ }^{35}$ But this moment does not last: he crashes at his parents' feet and dies. As an incarnation of the spirit of poetic heroism, Euphorion reaches great heights but cannot remain in the human world. One might imagine that the son of Tamino and Pamina, for a younger Goethe, could have been a Euphorion-like figure who can fly and who does enter and remain in the (human) world. Yet the pathos of Euphorion's urge to see the world and to fly is entirely absent from this earlier account. This spirit-child is not the incarnation of heroism in the face of the world's sorrows but a being whose nature is beyond heroism and beyond sorrow. Difficulty in fleshing out such an image-both in its genesis out of rupture and in the precise contours of its form-may have been part of the reason Goethe left this project a fragment. Perhaps he could not quite see how to get the boy, and the utopia he was to represent, both fully natural and fully human. And perhaps in the end he was simply uncomfortable with the notions he broached in the fragment and with their potential implications. For all the familiar Goethean themes we can find in the text, it is not merely, or not entirely, a step on the way to later works. There is a certain strangeness about it, a world of meaning potentially at variance with other works in Goethe's oeuvre. Though I have mentioned elements of this strangeness I have by no means exhaustively treated them.

\section{Conclusion}

In his sequel to Die Zauberflöte, Goethe reopens the world of the magic flute, only to relegate its oppositions and conflicts to the position of a generative mechanism, useful for waking up self-sufficient humanity but then to be left behind once that awakening has occurred. Yet while this may be an intellectually stimulating idea, if difficult to flesh out, ultimately this project may 
have been doomed to failure in the theater anyway. There were the difficulties Goethe experienced trying to find a composer willing and able to engage with Mozart on his own turf, of course. ${ }^{36}$ But more than that, audiences expecting a delightful repetition and continuation of an opera they knew and loved may have been quite disappointed not only by the music but also by the libretto. Borchmeyer claims, for instance, that no audience of the day would ever have forgiven Goethe for his rather pitiless parody and perversion of the flute. ${ }^{37}$ Whether one agrees with this assessment of Goethe's flute or not, Goethe did seem to have come to realize that it would be difficult to avoid disappointing with a sequel to Mozart's opera, for as time went on, a few musicians and others did express interest in completing the project, but Goethe himself was the one who refused to allow any further work on it. ${ }^{38}$

Perhaps he had begun to realize, after several frustrating experiences, that in the realm of opera Mozart would always stand far above him - for this was not Goethe's first competitive, if admiring, encounter with the composer. As Borchmeyer writes:

Es ist erstaunlich, mit welch wachem künstlerischen Instinkt der Nichtmusiker und musikalisch nicht einmal sonderlich begabte Goethe die Operntendenzen seiner Zeit erfaßt hat. Ob [Goethe] sich um das deutsche Singspiel bemühte, ob er eine Oper nach Beaumarchais' Le marriage de Figaro plante-immer entdeckte er, daß ihn jemand schon aus dem Felde schlug oder ihm zuvorgekommen war: Mozart, dessen Entführung aus dem Serail trotz ihres in Goethes Augen dürftigen Librettos "alles nieder schlug," was er selber auf dem Gebiet des Singspiels versucht hatte, wie er in der Italienischen Reise resigniert feststellt, und dessen Figaro, am 1. Mai 1786 in Wien uraufgeführt, Goethes eigenen Plan (einer Oper unmittelbar oder mittelbar nach der Komödie von Beaumarchais) schon in der ersten Entwurfsphase zunichte machte. Dem von Mozart geschlagenen Goethe blieb nichts anderes übrig, als sich dem siegreichen Genius gewissermaßen liebend zu unterwerfen: in Der Zauberföte zweiter Teil. ${ }^{39}$

I hope to have shown in this paper ways in which Goethe's sequel is not merely a Sichunterwerfen but an ambitious attempt to broach new ground beyond the world of the original opera and to address new cultural concerns through the thematics of sound. But in any case, even this final attempt by a geschlagenen Goethe could not come to fruition. And so, rather than produce his own Zauberflöte in Weimar, Goethe produced Mozart's. Over the course of his theater directorship, Die Zauberflöte appeared on the program an impressive eighty-nine times, more than any other operatic piece ${ }^{40}$ - and thus it is perhaps not too flippant to conclude with the words of another Mozart admirer, words that one might wish to put into Goethe's own mouth but that ultimately are as little appropriate to him as they are to the man who penned them:

I shall beg Mozart to forgive me, because his music did not inspire me to great deeds, but turned me into a fool, who lost through him the little reason I had, and spent most of my time in quiet sadness humming what I do not understand, haunting like a specter day and night what I am not permitted to enter. ${ }^{41}$ 
${ }^{1}$ Robert Spaethling, Music and Mozart in the Life of Goethe (Columbia, SC: Camden House, 1987) 29.

${ }^{2}$ In a letter of January 1796 written to Paul Wranitzky, music director of the Viennese court theaters, Goethe explains his reasons for writing such a piece: "Der grosse Beifall, den die Zauberflöte erhielt, und die Schwierigkeit, ein Stück zu schreiben, das mit ihr wetteifern könnte, hat mich auf den Gedanken gebracht, aus ihr selbst die Motive zu einer neuen Arbeit zu nehmen, um sowohl dem Publiko auf dem Wege seiner Liebhaberei zu begegnen als auch den Schauspielern und Theaterdirektionen die Aufführung eines neuen und komplizierten Stücks zu erleichtern. Ich glaube mein Absicht am besten erreichen zu können, indem ich einen zweiten Teil der 'Zauberflöte' schreibe, die Personen sind alle bekannt, die Schauspieler auf diese Charaktere geübt, und man kann ohne Übertreibung, da man das erste Stück schon vor sich hat, die Situationen und Verhältnisse steigern und einem solchen Stücke viel Leben und Interesse geben. Inwiefern ich meine Absicht erreicht habe, muss die Wirkung zeigen. Damit dieses Stück sogleich durch ganz Deutschland ausgebreitet werden könnte, habe ich es so eingerichtet, dass die Dekorationen und Kleider der ersten 'Zauberflöte' beinahe hinreichen, um auch den zweiten Teil zu geben. Wollte eine Direktion mehr darauf verwenden und ganz neue dazu anschaffen, so würde der Effekt noch grösser sein, ob ich gleich wünschte, dass, selbst durch die Dekorationen, die Erinnerung an die erste 'Zauberflöte' immer angefesselt bliebe." Quoted in Hedwig Walwei-Wiegelmann, ed., Goethe's Gedanken über Musik. Eine Sammlung aus seinen Werken, Briefen, Gesprächen und Tagebüchern (Frankfurt am Main: Insel, 1985) 187.

${ }^{3}$ Dieter Borchmeyer, Goethe, Mozart und die Zauberflöte (Göttingen: Vandenhoeck \& Ruprecht, 1994) 13. Der Zauberflöte Zweiter Teil, Borchmeyer concludes, "hatte seine Schuldigkeit getan und konnte nun Fragment bleiben" (ibid. 13). Of course, there were other reasons why the text remained a fragment, too, at least initially. After Goethe had completed a few scenes, he asked several composers to prepare the music, but none were willing. In part this may have been because none felt able to compete with Mozart's music, but in part too it was because of the high fee Goethe requested. When he approached Wranitzsky, Goethe requested 100 ducats; in response, Wranitzsky suggested some modifications of plan and considered 25 ducats to be sufficient as the librettist's fee for such a project. Walwei-Wiegelmann, Goethe's Gedanken über Musik 187.

${ }^{4}$ Goethe called himself a "Ton- und Gehörloser, obgleich Guthörender" in a letter to the composer C. F. Zelter dated May 2, 1820. Johann Wolfgang Goethe, Sämtliche Werke, Briefe, Tagebücher und Gespräche. II. Abteilung: Briefe, Tagebücher und Gespräche, Band IX: Vom 27. Oktober 1819 bis zum 26. Dezember 1822. (Frankfurt am Main: Deutscher Klassiker Verlag, 1999).

${ }^{5}$ Goethe's text has not generally been read in this way: for the most part, commentators have assumed in it more or less the same dualistic world-view that appears so prominently in Schikaneder's libretto (although Rose Subotnik and Carolyn Abbate, among others, have identified ways in which the original opera, too, breaks down the binary oppositions and Enlightenment values it appears to uphold. Cf. Rose Subotnik, "Whose Magic Flute? Intimations of Reality at the Gates of the Enlightenment," Deconstructive Variations: Music and Reason in Western Society. (Minneapolis: U of Minnesota P, 1996) 1-38. Cf. Carolyn Abbate, In Search of Opera. (Princeton and Oxford: Princeton UP, 2001) 58ff.)

${ }^{6}$ In 1810 Goethe did sketch a preliminary outline for a Tonlehre, conceived along the lines of his Farbenlehre and Der Zauberflöte zweiter Teil, though incomplete, shows early and artistically rewarding efforts to work out such ideas. Cf. Johann Wolfgang Goethe, Sämtliche Werke, Briefe, Tagebücher und Gespräche. Band XXV: Schriften zur allgemeinen Naturlehre, Geologie und Mineralogie (Frankfurt am Main: Deutscher Klassiker Verlag, 1989) 180-184.

${ }^{7}$ Friedrich Kittler, Aufschreibesysteme 1800/1900. 2nd enlarged and corrected ed. (München: Fink, 1987).

${ }^{8}$ Johann Wolfgang Goethe, Sämtliche Werke, Briefe, Tagebücher und Gespräche. Band VI: Dramen 1791-1832 (Frankfurt am Main: Deutscher Klassiker Verlag, 1993).

${ }^{9}$ This summary does not adequately represent the fragmentary nature of the libretto: the most fully developed scenes focus on the opening scene with Monostatos and the Queen, and on Papageno, whose thematic relation to the abduction and search for the princeling is not immediately obvious; while many crucial events of the plot are outlined only in barest essentials. Goethe's decision to develop those particular scenes first seems to have been inspired by 
Mozart's music for parallel scenes, particularly for the Queen's appearances and for Papageno's duet with Papagena. Thus when Papageno and his wife complain about having no children, for example, Goethe specifies each repetition and each transfer of speaker when they say "Pa-pa-pa" back and forth. Goethe, Sämtliche Werke, Briefe, Tagebücher und Gespräche, Volume VI 231.

${ }^{10}$ Wolfgang Amadeus Mozart, Die Zauberflöte. Ed. Hans-Albrecht Koch (Stuttgart: Reclam, 1991) 17.

${ }^{11}$ Borchmeyer writes: "Die Polarität von solarischer Geisteswelt und lunarischer Elementarwelt [ . . ] lässt an Goethes privaten Schöpfungsmythos denken, den er im achten Buch von Dichtung und Wahrheit nachgezeichnet hat und der von den polaren Tendenzen der 'Konzentration' und 'Expansion' bestimmt ist. Danach würde die Königin der Nacht das aus dem Chaos schaffende, durch die Beschränkung auf sich selbst von der Gottheit abfallende Prinzip der Konzentration verkörpern. [ . . . ] Der auf Abgeschlossenheit zielenden Welt der Königin steht die Offenheit des Priesterordens gegenüber, dessen Gebot der alljährlichen Wanderschaft oder Pilgerschaft eines Mitglieds des Ordens dem expansiven Prinzip in Goethes Schöpfungsmythos korrespondiert." Goethe, Mozart und die Zauberflöte 22.

${ }^{12}$ There is also Monostatos' curse to contend with, of course, and by removing the child from the palace the servants lessen the danger that the parents might look at him and thereby occasion his death. Yet there is no indication that the priests know of the curse, and in any case the instructions to the care-takers focus not on removal from the palace but on movement itself. Yet the suggestion that the child's life depends on movement per se turns out not to be correct or complete in a strictly literal sense, for after the casket falls into the Queen's hands it is no longer carried about, yet the child survives. Here the fragmentary nature of the text makes further explanation impossible.

${ }^{13}$ Schikaneder's libretto-and of course Mozart's music-also contains elements that point, in a general sense, to a third realm of experience that escapes the binary opposition between light and dark. Sound-represented by the Zauberflöte, the Glockenspiel, and the three boys, whom Subotnik has described as "characters who exist in a pure sound realm" and may in some ways be of the same order of being as Goethe's boy-spirit — cannot be fixed to the world of light nor the world of night. The instruments and the boys appear in the complicated intricacies of the plot to be serving both the Queen and Sarastro. If we were to read backward from Goethe's sequel, one way to make sense of their apparent side-switching midcourse would be to conclude - as Goethe himself may have done - that in truth they served neither one side nor the other, but rather belonged to an alternative world-order (based more on sound than on light), and that their interactions with the Queen and Sarastro were governed by a different logic that would relativize the conflict between the two. Cf. Subotnik, "Whose Magic Flute?" 34.

${ }^{14}$ The Queen, attempting to convince Pamina to murder Sarastro, tells her: [Your father] [ü]bergab freiwillig den siebenfachen Sonnenkreis den Eingeweihten; diesen mächtigen Sonnenkreis trägt Sarastro auf seiner Brust.-Als ich ihn darüber beredete, so sprach er mit gefalteter Stirne: "Weib! meine letzte Stunde ist da—alle Schätze, so ich allein besaß, sind dein und deiner Tochter."- "Der alles verzehrende Sonnenkreis," fiel ich ihm hastig in die Rede"ist den Geweihten bestimmt," antwortete er: "- Sarastro wird ihn so männlich verwalten, wie ich bisher-—Und nun kein Wort weiter; forsche nicht nach Wesen, die dem weiblichen Geiste unbegreiflich sind.-Deine Pflicht ist, dich und deine Tochter der Führung weiser Männer zu überlassen.” Mozart, Die Zauberflöte 47.

${ }^{15}$ Tamino had entered the world of Die Zauberflöte in a desperate flight from a snake-like monster: he begins the opera by singing, "Zu Hilfe! Zu Hilfe! Sonst bin ich verloren, / Der listigen Schlange zum Opfer erkoren" (7). Falling unconscious before the beast, he does not see the three ladies who save him, but rather, upon awakening, meets Papageno, who is surprised to learn that beyond the mountains there are more lands and people. Tamino tells him: "Mein Vater ist Fürst, der über viele Länder und Menschen herrscht; darum nennt man mich Prinz" (10) - though he had not been acting in a particularly princely way.

${ }^{16}$ Mozart, Die Zauberflöte 66-68.

${ }^{17}$ Goethe's stage directions indicate that it is "wohl überflüssig zu bemerken, daß es ganz von dem Komponisten abhängt, den Übergang von Zufriedenheit und Freude zu Schmerz und Verzweiflung, nach Anlaß vorstehender Verse, zu verschränken und zu wiederholen" (245).

${ }^{18}$ Borchmeyer, Goethe, Mozart und die Zauberflöte 27.

${ }^{19}$ Borchmeyer, Goethe, Mozart und die Zauberflöte 27. 
20 "Der Deckel des Kastens springt auf. Es steigt ein Genius hervor, der durch die Lichter, welche den Kasten transparent machten, ganz erleuchtet ist, wenn die Lichter so disponiert sind, dass die obere Hälfte der übrigen Figuren gleichfalls mit erleuchtet ist." Goethe, Sämtliche Werke, Briefe, Tagebücher und Gespräche, Volume VI 248.

${ }^{21}$ Kittler, Aufschreibesysteme 1800/1900 64.

${ }^{22}$ Pestalozzi, Sämtliche Werke, Band XVI: Schriften aus der Zeit von 1803-1804. Bearbeitet von Walter Feilchenfeld und Herbert Schönebaum (Berlin und Leipzig: de Gruyter, 1935) 266.

${ }^{23}$ Kittler, Aufschreibesysteme 1800/1900 64.

${ }^{24}$ Pestalozzi, Sämtliche Werke, Band XVI 265.

${ }^{25}$ Mozart, Die Zauberflöte 48.

${ }^{26}$ I adopt this phrase from Carolyn Abbate, who writes that "[Paul] Robinson hears opera in a way that has nothing to do with the events that its libretto depicts; he hears it as sonorous texture." Carolyn Abbate, Unsung Voices. Opera and Musical Narrative in the Nineteenth Century (Princeton, NJ: Princeton UP, 1991) ix.

${ }^{27}$ Ibid. 10-11.

${ }^{28}$ Abbate does not explain to whom the Queen's aria is so terrifying, and in her later book In Search of Opera (2001) she provides a substantially different account of it as "strange in a way that disarms the very fear that threatens one's astonishment" (94). But many aspects of Goethe's text fit in well with her earlier description of a universal response of terror, and the sequel's obsession with the Queen is everywhere apparent, from the care devoted to the opening scene to his emphasis on Pamina's motherly love.

${ }^{29}$ Abbate, Unsung Voices 11.

${ }^{30}$ Rousseau, Essai sur l'origine des langues. Introduction et notes par Angèle Kremer-Marietti (Paris: Éditions Aubier Montaigne, 1974) 160.

${ }^{31}$ Rousseau, Essai sur l'origine des langues 160.

${ }^{32}$ Kittler, Aufschreibesysteme 1800/1900 64.

${ }^{33}$ Borchmeyer, Goethe, Mozart und die Zauberflöte 24.

${ }^{34}$ Goethe, Sämtliche Werke, Briefe, Tagebücher und Gespräche. Volume VII/1: Faust, Texte (Frankfurt am Main: Deutscher Klassiker Verlag, 1994) 383.

${ }^{35}$ Ibid.

${ }^{36}$ Schiller drove this point home in a letter of May 11, 1798: "Wenn Sie zu der Fortsetzung der Zauberflöte keinen recht geschickten und beliebten Komponisten haben, so setzen Sie sich, fürcht ich, in Gefahr, ein undankbares Publikum zu finden, denn bei der Repräsentation selbst rettet kein Text die Oper, wenn die Musik nicht gelungen ist, vielmehr läßt man den Poeten die verfehlte Wirkung mit entgelten.” Goethe, Sämtliche Werke, Briefe, Tagebücher und Gespräche, Volume VI 1046.

${ }^{37}$ Borchmeyer, Goethe, Mozart und die Zauberflöte 26.

${ }^{38}$ Goethe, Sämtliche Werke, Briefe, Tagebücher und Gespräche, Volume VI 1048.

${ }^{39}$ Borchmeyer, Goethe, Mozart und die Zauberflöte 9-10.

${ }^{40}$ Goethe, Sämtliche Werke, Briefe, Tagebücher und Gespräche, Volume VI 1044. Spaethling, Music and Mozart in the Life of Goethe 29.

${ }^{41}$ Søren Kierkegaard, "The Immediate Stages of the Erotic or The Musical Erotic" in Either/Or, Volume I. Translated by David F. Swenson and Lillian Marvin Swenson (Garden City, NY: Doubleday, 1959) 46-47. 